Original Contribution

\title{
FUNGAL DIVERSITY IN MEDITERRANEANAND SUB-MEDITERRANEAN PLANT COMMUNITIES OF SAKAR MOUNTAIN
}

\author{
M. Lacheva* \\ Department of Botany and Agrometeorology, Agricultural University, Plovdiv, Bulgaria
}

\begin{abstract}
The present study reports 113 larger fungi in Mediterranean and sub-Mediterranean plant communities of Mt Sakar. All taxa are new to Mt Sakar. Of these, 88 species are reported for the first time from Toundzha Hilly Country. The predominant part of species belongs to the class Agaricomycetes (110 species), other part belongs to the Pezizomycetes (3 species). Nine species are included in the Red List of fungi in Bulgaria and Red Data Book of the Republic of Bulgaria, namely Agaricus macrocarpus, Amanita caesarea, A. vittadinii, Bovista graveolens, Clathrus ruber, Chlorophillum agaricoides, Geastrum triplex, Phallus hadriani, and Tulostoma fimbriatum. One species is rare and threatened in Bulgaria and Europe Phallus hadriani. The following steppe, xerothermic, and thermophilous fungi deserve special attention: Agaricus bernardii, Entoloma incanum, Hygrocybe virginea, H. persistens, Lepiota alba, and Leucopaxillus lepistoides. The aim of the paper is to enrich the information about fungal diversity of the Mt Sakar, which area appears to be important for conservation of the fungal diversity in Bulgaria.
\end{abstract}

Key words: fungal conservation, fungal diversity, larger fungi, Mediterranean and sub-Mediterranean plant communities, Mt Sakar

\section{INTRODUCTION}

Mt Sakar is situated in Southeast Bulgaria, in the southeastern part of the Balkan Peninsula.

Besides the European and Macedonian-Thracian floristic elements, there are also Euxinian floristic elements, steppe, and Mediterranean species and therefore, Mt Sakar has been set apart into an independent region of the Macedonian-Thracian Province (1).

It falls within the Continental-Mediterranean climatic region (2). Summers are warm and winters are mild, without lasting snow cover and with small temperature amplitudes. The climate of the area is influenced considerably by the Black Sea and is predominantly transitional to Mediterranean. Major riversin the area are river Tundzha and the river Marica. According to the physical and geographical regionalisation, the mountain is situated within the Toundzha region

* Correspondence to: Maria Lacheva, Department of Botany and Agrometeorology, Agricultural, University-Plovdiv, 12, Mendeleev Str., 4000 Plovdiv, Bulgaria,e-mail: agaricus@abv.bg
$(3,4)$. The highest peak in the Mt Sakar is peak Vishegrad $(856 \mathrm{~m})$.

Mt Sakar mainly constitutes of old Paleozoic metamorphic and granite rocks, with some limestone out crops. Soil cover in the Sakar is represented by shallow leached and strongly leached to podzolized cinnamon-forest soils. The predominant soil types are cinnamon-podzolic soils (5).

In the composition of the plant communities participate trees, shrubs and herbaceous species, many of which are with Mediterranean and subMediterranean distribution. Forests are dominated by Quercus cerris, $Q$. frainetto, $Q$. pubescens, $Q$. virgiliana, Tilia rubra, Ulmus minor etc. Typical representatives of shrub and herbaceous plants (Bothriochloa ischaemum, Chrysopogun gryllus, Poa bulbosa etc.) are some Mediterranean species as Jasminum fruticans, Ilex aquifolium, Paliurus spina-christi, Phillyrea latifolia, Ruscus aculeatus etc. There are also typical sub-Mediterranean communities presented by Carpinus orientalis, Fraxinus ornus, Ostrya carpinifolia, Populus nigra, Rosa 
canina etc. (6).

The fungal diversity not been well studied not only in Mt Sakar, but in all floristic regions Toundzha Hilly Country (7-9). A summary overview of macromycetes in Mediterranean and sub-Mediterranean plant communities of Bulgaria provides (10). The macrofungi of $\mathrm{Mt}$ Sakar are extremely poorly known. There have been only sporadic records of single species (11), but no study has been specifically directed at investigation of the fungal diversity of $\mathrm{Mt}$ Sakar.

The aim of this paper is to present recent, systematically collected data on the fungal diversity in Mediterranean and subMediterranean plant communities of Mt Sakar.

\section{MATERIAL AND METHODS \\ Study area}

The current research is based on larger fungi collected from Mt Sakar and its environs between 2009 and 2011.

\section{List of locations}

\section{Topolovgrad Municipality}

1. Hlyabovo village at Cheshmite locality, on northwestern slope near the granite quarry, mixed forest from Quercus rubra and Pinus nigra, 10.10.2009, 27.09.2011.

2. Svetlina village at Rubin kamak locality, in open place above the dam, 10.10.2009, 27.09.2011.

3. Kapitan Petko Voivoda village at Gubal Karagach locality, in a culture of Populus nigra, above the catchment, 10.10.2009, 25.05.2011, 20-22.09.2011.

4. Sakartsi village at Elenovi grobishta locality, under the peak Visegrad, in meadow near deciduous forest from Quercus cerris, 10.10.2009, 25.05.2011, 20-22.09.2011.

5. Sinapovo village at Trapsata locality, along the upper part of a road, near Pinus nigra culture, 10.10.2009, 25.05.2011, 20-22.09.2011.

6. Chukarovo village at Mandrata locality, on northern slopes of the Sakar Mountain, mixed forest with Fraxinus sp., Quercus sp., and Pinus nigra, 10.10.2009, 25.05.2011, 20-22.09.2011.

7. Oreshnik village at Varbite locality, oak forest, along the upper part of a road, in the ravine under the dry lake, 10.10.2009, 2022.09.2011.

8. Dobroselec village at Treskovo kladenche locality, in Robinia pseudoacacia culture, nearly northern slopes of the Sakar Mountain, 10.10.2009, 25.05.2011, 20-22.09.2011
9. Ustrem village, near Sveta Troica monastery, deciduous forest of Quercus sp., and Q. cerris, 10.10.2009, 20-22.09.2011.

10. Mramor village, at Treskovo kladenche locality, on northern slopes of the Sakar Mountain, deciduous forest of Quercussp., and Q. cerris, 10.10.2009, 20-22.09.2011.

11. Along the road between Sakartsi and Hlyabovo villages, in meadow with Paliurus spina-christi, 10.10.2009, 20.09.2011.

12. Along the road between Radovets and Ustrem villages, in meadow with Paliurus spinachristi, 10.10.2009, 20-22.09.2011.

13. Along the road between Planinovo and Orlov Dol villages, in meadow with Paliurus spinachristi, 10.10.2009, 20.09.2011.

14. Along the road between Balgarska polyana and Hlyabo vovillages, Byalata treva locality, the slope above the dam, 10.10.2009, 20.09.2011.

\section{Elhovo Municipality}

15. Lesovo village at Kaleto locality, deciduous forest of Fraxinus sp., Quercusfrainetto, and $Q$. pubescens, under southern slope above the Tunja river,11.09.2009, 25.05.2011, 18.10.2011.

16. Lesovo village, near Derventski Heights, in deciduous forest of Fraxinus sp., Quercus frainetto, and $Q$. pubescens, 11.09.2009, 25.05.2011, 18.10.2011.

17. Melnitsa village, near cave Dranchidupka, deciduous forest of Fraxinus sp., Quercus frainetto, and $Q$. pubescens, 11.09.2009, 25.05.2011.

18. Golyam Dervent village, near Derventski Heights, deciduous forest of Fraxinus sp., and Quercus frainetto, 11.09.2009, 25.05.2011.

19. Malak Manastir at Ivanovoto locality, deciduous forest of Quercussp., and Fraxinus sp. 11.09.2009, 25.05.2011.

20. Arapliyska river between Chernozem and Granitovo villages at Padaloto localiry, deciduous forest of Quercus sp., and Fraxinus sp., 11.09.2009, 25.05.2011.

\section{Svilengrad Municipality}

21. Kostur village at Petkova cheshma locality, in meadow of slope above the pumping station, 10.10.2009, 25.05.2011, 20-22.09.2011.

22. Matochina village at Ravna polyana locality, in meadow, 02.09.2010, 13-14.10.2010, 18.10.2011.

23. Levka village, in the valley of the Levka River, Stara Levka locality, in meadow, 02.09.2010, 13-14.10.2010, 18.10.2011.

24. Lesovo village at Dalak Bunar locality, in the forest to the road, 02.09.2010, 13-14.10.2010, 18.10.2011. 
25. Mihalich village at Lokvata locality, in stony meadows, 02.09.2010, 13-14.10.2010, 18.10.2011.

26. Mustrak village at Enev rut locality, stony meadows under granite slope with southern inclination, $\quad 02.09 .2010, \quad 13-14.10 .2010$, 18.10.2011.

27. Dervishka Mogila at Mogilata locality, meadow nearly to mounds, 02.09.2010, 1314.10.2010, 18.10.2011.

28. Studen village, at the foot of Dervish Mogila peak, mixed forest of Fraxinus sp., Quercus sp., and Pinus nigra, 02.09.2010, 13-14.10.2010.

\section{Harmanli Municipality}

29. Cherepovo village at Golyamata cheshma locality, in meadow over wild vines, near oak forest of Quercus cerris, 10.10.2009, 25.05.2011, 20-22.09.2011.

30. Cherepovo village at Sovanluka locality, in grassland, 10.10.2009, 25.05.2011, 2022.09.2011.

31. Dripchevo village at Tuzla locality, deciduous forest of Quercus sp., and Q. cerris near almond culture, 10.10.2009, 25.05.2011, 20-22.09.2011.

32. Dripchevo village at Shirokiya Alchak locality, deciduous forest of Quercussp., and $Q$. cerris at the southern foot of the Sakar Mountain, 10.10.2009, 25.05.2011, 2022.09.2011.

33. Bulgarin village at Druma locality, oak forest above the village, along the valley of the Maritsa river, 02.09.2010, 13-14.10.2010.

34. Dositeevo village at Kaleto locality, oak forest above the village, 02.09.2010, 1314.10.2010.

35. Izvorovo village at Cheshmite locality, oak forest above the village, along the valley of the Maritsa River, 02.09.2010, 13-14.10.2010.

36. Maritsa River between Shishmanovo and Bulgarin villages, near Harmanli town, in thickets, 02.09.2010, 13-14.10.2010.

\section{Collection, determination, nomenclature and keeping of the fungal samples}

Studied specimens are kept in the Agricultural University (SOA) in Plovdiv; their accession numbers are given in brackets atthe end of each record. Specimens were collected by the author, unless other wise stated. Identification and taxonomy of the specimens was performed according to (12-29).

The nomenclature follows (30). The author's names of the taxa are abbreviated according to (31).
The conservation status is indicated according to the Red List of fungi in Bulgaria (32).

\section{RESULTS AND DISCUSSION \\ List of species}

(* new to Toundzha Hilly Country, CV conservation value)

1. *Agaricus arvensis Schaeff. - 2 (on soil, in open place above the dam), 3 (along the catchment under Populus nigra), 8 (in Robinia preudoacacia culture), 10 (in meadow, near deciduous forest of Quercus sp.), 11 (in meadow with Paliurus spina-christi), 12 (in meadow with Paliurus spina-christi), 13 (in meadow with Paliurus spina-christi), 22 (in meadow), 29 (in meadow, above wild vines), 31 (on sandy soil, in almond culture).

2. *A. bernardii Quél. - 14 (on sandy soil), 27 (stony meadow to the mounds).

3. *A. campestrisL. : Fr. -2 (in open meadow above the dam), 3 (along the catchment under Populus nigra), 8 (in Robinia pseudoacacia culture), 9 (in meadow above oak forest), 11 (in meadow with Paliurus spina-hristi), 13 (in meadow with Paliurus spina-christi), 17 (on sandy soil), 25 (in rocky meadow), 26 (in rocky meadow), 29 (in pasture above wild vines), 34 (in oak forest), 36 (in thickets to road).

4. *CVA. macrocarpus (F.H. Møller) F.H. Møller - 4 (in meadow near deciduous forest), 18 (in meadow near deciduous forest), 27 (in thickets to mounds), 31 (in almond culture).

5. A. pseudopratensis (Bohus) Wasser -2 (on soil, in open place above the dam), 3 (along the catchment under Populus nigra).

6. *A. xanthodermus Genev. -2 (on soil, under Populus nigra), 7 (in oak forest, in the ravine under the dry lake), 8 (in culture of Robinia pseudoacacia), 22 (in meadow), 36 (roadside, in thickets).

7. *CVAmanita caesarea (Scop. : Fr.) Pers. -4 (on soil, in oak forest), 15 (on soil, in deciduous forest), 24 (on soil, roadside, in oak forest).

8. *A. pantherina (D.C. : Fr.) Krombh. - 31 (on soil, in oak forest), 32 (on soil, in oak forest).

9. *A. rubescens Pers. : Fr. - 24 (on soil, roadside, in oak forest), 28 (on soil, in thickets).

10. ${ }^{*} C V$ A. vittadinii (Moreti) Vittad. - 13 (in meadow with Paliurus spina-christi), 29 (in meadow).

11. *Agrocybe molesta (Lasch) Singer - 11 (on soil, in meadow with Paliurus spina-christi), 13 (in meadow with Paliurus-spina christi). 12. *A. praecox (Pers. : Fr.) Fayod - 2 (on soil, in open place above the dam), 8 (on soil, in the Robinia pseudoacacia culture). 
13. *Boletus edulis Bull. : Fr. - 15 (on soil, in oak forest), 24 (on soil, in mixed forest), 31 (on soil, in oak forest), 36 (on soil, in thickets).

14. *B. aereus Bull. : Fr. -15 (on soil, in oak forest), 24 (in oak forest, in oak forest).

15. *B. luridus Schaeff. : Fr. - 31 (on soil, in oak forest), 33 (on soil, in oak forest).

16. B. chrysenteron Bull. : Fr. - 1 (on soil, in mixed forest), 4 (in oak forest), 32 (on soil, in oak forest).

17. *CV Bovista graveolens Schwalb - 5 (in meadow near Pinus nigra culture), 6 (in mixed forest).

18. Bovista plumbea Pers. : Pers. -3 (along the catchment under Populus nigra), 13 (in meadow with Paliurus spina-christi), 26 (in rocky meadow), 29 (in pasture, above wild vines).

19. *Calocybe gambosa (Fr. : Fr.) Donk - 3 (alongthe catchment under Populus nigra), 18 (in deciduous forest).

20. *Calvatia gigantea (Batsch : Pers.) Lloyd -4 (in meadow near deciduous forest), 18 (on sandy soil, along deciduous forest).

21. *Calvatia utriformis (Bull. : Pers.) Jaap. -3 (on soil, along the catchment under Populus nigra), 13 (in meadow with Paliurus spinachristi), 21 (in meadow, in thickets).

22. Cantharellus cibarius Fr. - 2 (on soil, in deciduous forest), 6 (on soil, in mixed forest), 26 (on soil, in deciduous forest).

23. CV Chlorophillum agaricoides (Czern.) Vellinga - 29 (in pasture), 30 (in pasture).

24. Chlorophillum rachodes (Vittad.) Vellinga 3 (along the catchment under Populus nigra), 29 (on pasture above wild vines), 30 (on pasture).

25. *CV Clathrus ruber [P. Micheli ex] Pers. : Pers. - 5 (nearly the Pinus nigra culture), 6 (on sandy soil, in deciduous forest).

26. Clitocybe gibba (Pers. : Fr.) P. Kumm. - 1 (on soil, in mixed forest), 4 (on soil, in deciduous forest), 31 (on soil, in oak forest), 34 (in oak forest).

27. C. rivulosa (Pers. : Fr.) P. Kumm. -4 (in deciduous forest), 6 (in mixed forest).

28. *Clitopilus prunulus (Scop. : Fr.) P. Kumm. -31 (on soil, in oak forest near almond culture).

29. * Conocybe apala (Fr. : Fr.) Arnolds - 2 (on soil, in deciduous forest), 26 (on soil, in deciduous forest), 29 (in meadow above wild vines).

30. *Conocybe subovalis Kühner \& Watling 13 (in meadow with Paliurus spina-christi), 21 (in meadow nearly deciduous forest).

31. *Coprinellus micaceus (Bull. : Fr.) Vilgalys, Hopple \& Jacq. Hohnson. - 7 (on soil, in mixed forest, in the ravine under the dry lake), 31 (on soil, in oak forest near almond culture).
32. Coprinopsis atramentaria (Bull. : Fr.) Redhead, Vilgalys \& Moncalvo - 4 (on manure near deciduous forest), 29 (in meadow above wild vines).

33. *Coprinopsis nivea (Pers. : Fr.) Redhead, Vilgalys \& Moncalvo - 31 (on horse excremen tnearly oak forest and almond culture).

34. *Coprinus comatus (O.F. Müll. : Fr.) Pers. 2 (on soil, in open meadow), 8 (in Robinia pseudoacacia culture), 29 (on soil, in meadow above wild vines).

35. *Cortinarius cotoneus Fr. - 1 (on soil, in mixed forest), 15 (on soil, in deciduous forest), 31 (on soil, in oak forest near almond culture).

36. ${ }^{*}$ C. infractus (Pers. : Fr.) Fr. -6 (in deciduous forest), 32 (in oak forest).

37. ${ }^{*}$ C. torvus (Fr.: Fr.) Fr. -4 (on soil, in deciduous forest), 32 (on soil, in oak forest), 33 (on soil, in oak forest).

38. *Craterellus cornucopioides (L. : Fr.) Pers. 11 (in meadow with Paliurus spina-christi), 12 (in meadow with Paliurus spina-christi), 14 (on soil, in thickets).

39. *Crepidotus mollis (Schaeff. : Fr.) Staude -1 (on wood of deciduous trees, in mixed forest), 31 (on wood, in oak forest near almond culture), 32 (on wood, in oak forest), 33 (on soil, in oak forest).

40. ${ }^{*}$ C. variabilis (Pers. : Fr.) P. Kumm. -6 (in meadow, above the deciduous forest), 9 (on wood, above the oak forest).

41. *Crinipellis scabella (Alb. \& Schwein. : Fr.) Murrill - 12 (on litter, in thickets with Paliurus spina-christi), 29 (on litter, in thickets with Quercus sp.), 31 (on litter, in oak forest).

42. *Daedalea quercina (L. : Fr.) Pers. - 6 (on wood, above the mixed forest), 15 (on wood, in deciduous forest), 31 (on wood, in oak forest near almond culture).

43. *Entoloma clypeatum (L. : Fr.) P. Kumm. 4 (on soil, in deciduous forest), 5 (along Pinus nigra culture).

44. *E. incanum (Fr. :Fr.) Hesler - 5 (on soil along Pinus nigra culture), 9 (in meadow, nearly deciduous forest).

45. *E. sinuatum (Bull. ex Pers. : Fr.) P. Kumm. -31 (on soil, in oak forest).

46. *Exidia plana (F.H. Wigg.) Donk. - 28 (on rotten wood of deciduous trees), 34 (on wood of Quercus robur L., in oak forest).

47. Fistulina hepatica (Schaeff. : Fr.) With. -6 (on wood, in mixed forest), 15 (on wood, in deciduous forest), 31 (at base of Quercus robur). 48. *Flammulina velutipes (Curtis : Fr.) Singer 1 (on wood, in mixed forest), 24 (on wood of deciduous trees, in oak forest). 
49. Fomes fomentarius (L.) J. Kickx f. - 1 (on wood, in mixed forest), 24 (on wood of deciduous trees, in oak forest).

50. Ganoderma adspersum (Schulzer) Donk - 27 (on wood, in oak forest near mounds), 32 (on wood of deciduous trees, in oak forest).

51. G. lucidum (Curtis : Fr.) P. Karst. - 19 (at the base of Quercus sp.), 31 (on Quercus robur), 34 (at the base of Quercus sp., in oak forest).

52. G. Resinaceum Bond. - 6 (on wood, in mixed forest), 20 (on wood, in deciduous forest). 53. *Geastrum corollinum (Batsch) Hollós - 10 (in deciduous forest), 31 (on sandy soil near oak and almond forest).

54. *G. fornicatum (Huds.) Hook. -3 (along the catchment under Populus nigra), 9 (in oak forest), 26 (in meadow along deciduous forest), 33 (in oak forest).

55. $* G$. minimum Schwein. -9 (on soil, in meadow above oak forest), 10 (on soil, in meadow above deciduous forest from Quercus sp.), 25 (on stony meadow).

56. ${ }^{*} G$. pectinatum Pers. : Pers. -6 (in mixed forest), 22 (in meadow), 30 (in pasture).

57. *G. striatum DC. -21 (on soil, in meadow), 32 (on soil, in oak forest).

58. ${ }^{*} C V$ G. triplex Jungh. - 29 (on soil, in meadow above wild vines), 32 (on soil, in oak forest).

59. *Geopora arenicola (Lév.) Kers - 12 (on sandy soil, in meadow with Paliurus spinachristi), 14 (on sandy soil).

60. *Gymnopus dryophilus (Bull. : Fr.) P. Murille - 19 (on litter, in deciduous forest), 20 (on litter, in deciduous forest).

61. *Gymnopus peronatus (Bolton : Fr.) Antonín, Halling \& Noordel. - 5 (on soil nearly Pinus nigra culture), 28 (on litter, in mixed forest; in thickets).

62. *Hyphodontia radula (Fr. : Fr.) Langer \& Vesterh. - 10 (on decaying wood, in oak forest), 28 (on decaying wood, in deciduous forest).

63. Hygrocybe conica (Schaeff. : Fr.) P. Kumm.

-1 (on soil, in mixed forest), 5 (on soil nearly

Pinus nigra culture).

64. *Hygrocybe virginea (Wulfen : Fr.) P.D. Orton \& Watling - 16 (in meadow along deciduous forest), 30 (in meadow).

65. ${ }^{*} H$. miniata (Fr. : Fr.) P. Kumm. - 16 (on soil among Sphagnum sp.).

66. *H. persistens (Britzelm.) Singer -6 (on soil, in grasslands).

67. *H. psittacina (Schaeff. : Fr.) P. Kumm. -16 (on soil among mosses, in mixed forest).

68. *Inocybe asterospora Quél. - 9 (on soil, among mosses near oak forest), 16 (in thickets).
69. I. rimosa (Bull. : Fr.) P. Kumm. - 1 (on soil, in mixed forest), 5 (in Pinus nigra culture).

70. *Lactarius azonites (Bull.) Fr. - 6 (on soil, in mixed forest), 32 (on soil, in oak forest), 35 (on soil, in oak forest).

71. * L. chrysorrheus Fr. - 31 (on soil, in oak forest near almond culture), 32 (on soil, in oak forest).

72. *L. zonarius (Bull.) Fr. - 32 (on soil, in oak forest).

73. *Laetiporus sulphureus (Bull. : Fr.) Mürrill 2 (in the base of Quercus sp., in deciduous forest), 6 (on Carpinus betulus L., in mixed forest).

74. *Leucopaxillus lepistoides (Maire) Singer 16 (in meadow, along deciduous forest), 29 (in meadow above wild vines).

75. *Lepiota cristata (Bolton. : Fr.) P. Kumm. 31 (on soil, in oak forest near almond culture).

76. Lepista flaccida (Sowerby : Fr.) Pat. - 6 (on soil, in mixed forest), 32 (on soil, in oak forest).

77.*L. erminea (Fr. : Fr.) P. Kumm. - 16 (on soil, in deciduous forest), 34 (on soil, in oak forest).

78. *L. personata (Fr. : Fr.) Cooke - 21 (on soil, in meadow), 29 (in meadow above wild vines).

79. *Lycoperdon echinatumPers. : Pers -6 (in mixed forest), 10 (in meadow, near deciduous forest).

80. * ${ }^{*}$. lividumPers -36 (on sandy soil, in meadow with Populus nigra, along the Maritsa river).

81. *L. perlatumPers. : Pers. - 12 (on soil, in meadow with Paliurus spina-christi), 21 (in meadow near deciduous forest), 35 (on soil, in oak forest).

82. *L. pyriforme Schaef. : Pers. - 9 (on decaying tree stumps, of oak tree in deciduous forest from Quercus sp., and Q. cerris), 10 (on well-rotted fallen branches, in oak tree in deciduous forest).

83. Marasmius oreades (Bolton : Fr.) Fr. -21 (on soil, in meadow), 26 (on soil, in meadow), 29 (in meadow above wild vines), 30 (on soil, in pastures), 35 (in meadow nearly oak forest).

84. ${ }^{*} M$. rotula (Scop. : Fr.) -6 (on fallen twigs of deciduous trees in mixed forest), 31 (on dead wood of oak tree in deciduous forest), 32 (on fallen twigs of deciduous trees in deciduous forest).

Macrolepiota excoriata (Schaeff. : Fr.) Wasser 3 (on soil under poplars near the catchment), 21 (on soil, in meadow), 29 (on soil, in meadow above wild vines).

85. M. procera (Scop. : Fr.) Singer -4 (on soil, in meadow nearly deciduous forest), 8 (on soil, in Robinia pseudoacacia culture), 22 (on soil, in 
meadow), 23 (on soil, in meadow), 32 (on soil, nearly oak forest).

86. *Panaeolus sphinctrinus (Fr.) Quél. - 8 (on excrement, in Robinia pseudoacacia culture), 21 (on excrement, in meadow), 25 (on excrement, in stony meadows).

87. *Octospora humosa (Fr. : Fr.) Dennis -32 (on soil, among mosses in oak forest).

88. *Peziza repanda Pers. - 16 (on soil, among mosses along deciduous forest), 29 (on soil, in pastures over wild vines).

89. *CV Phallus hadriani Vent. : Pers. -8 (on soil, in Robinia pseudoacacia culture), 32 (on soil, in oak forest).

90. Pleurotus eryngii (DC. : Fr.) Quél. - 2 (open meadow above the dam), 21 (in meadow), 22 (in meadow), 29 (in pasture above wild vines).

91. Pluteus cervinus (Schaeff.) P. Kumm. - 31 (on dead wood, in almond culture), 32 (on stump of deciduous tree, in oak forest).

92. Polyporus brumalis (Pers. : Fr.) Fr. - 16 (on dead wood, in deciduous forest), 31 (on dead wood, in oak forest to almonds culture).

93. *Polyporus leptocephalus (Jacq. : Fr.) Fr. -4 (on dead wood, nearly oak forest), 32 (ondeadwood, in oak forest).

94. Psathyrella candolleana (Fr. : Fr.) Maire - 3 (on wood of poplar along the catchment), 16 (on wood of deciduous trees, in deciduous forest).

95. *Pycnoporus cinabarinus (Jacq. : Fr.) P. Karst. - 14 (on dead wood), 32 (on wood, in oak forest).

96. *Russula fellea (Fr. : Fr.) Fr. - 6 (on soil, in mixed forest), 32 (on soil, in oak forest).

97. R. Foetens (Pers. : Fr.) Fr. -7 (on soil, in oak forest), 32 (on soil, in oak forest).

98. *R. maculata Quél. \& Rose - 6 (on soil, in mixed forest), 18 (on soil, in deciduous forest). 99. R. ochroleuca (Pers.) Fr. -4 (on soil, in meadow nearly deciduous forest).

100. *R. queletii Fr. - 31 (on soil, in oak forestnear almond culture), 32 (on soil, in oak forest).

101. *R. vesca Fr. -7 (on soil, in oak forest), 17 (on soil, in deciduous forest), 31 (on soil, in oak forest).

102. *Scleroderma verrucosum (Bull. : Pers.)

Pers. -8 (on soil, in Robinia pseudoacacia culture), 29 (on dirt road above wild vines), 30 (on dirt road along the pasture).

103. Schizophyllum commune Fr. : Fr. - 4 (on $\log$ of deciduous tree, in deciduous forest), 31 (on $\log$ of deciduous tree, in oak forest), 32 (on deadwood, in oak forest).

104. *Stereum hirsutum (Willd. : Fr.) Gray -4 (on wood of deciduous tree, in deciduous forest), 6 (on wood of deciduous tree, in deciduous forest), 18 (on wood of deciduous tree, in deciduous forest), 31 (on stump of deciduous tree, in oak forest).

105. *S. rugosum (Pers. : Fr.) Fr. - 32 (on deadwood, in oak forest), 35 (on deadwood, in oak forest).

106. *Stropharia coronilla (Bull. : Fr.) Fr. -5 (on soil, in grasslands above Pinus nigra culture), 18 (on soil, in mixed forest), 31 (on soil, in oak forest near almond culture), 32 (on soil, in oak forest), 35 (on soil, in oak forest), 36 (on manure, roadside, near Harmanli town).

107. *Suillus collinitus (Fr.) Kuntze - 5 (on soil nearly Pinus nigra culture).

108. Trametes versicolor (L. : Fr.) Lloyd - 6 (on stump of deciduous tree, in mixed forest), 33 (on stump of deciduous tree, in oak forest).

109. *Tulostoma brumale Pers. : Pers. -14 (on sandy soil), 30 (on dirt roadalong the pasture).

110. *CV T. fimbriatum Fr. - 11 (on sandy soil, on dry meadow with Paliurus spina-christi), 14 (on sandy soil, near dry meadow), 21 (on sandy soil, near dry meadow), 23 (on soil, near dry meadow), 27 (on soil, near mounds).

111. *T. melanocyclum Bres. - 12 (on soil, in meadow with Paliurus spina-christi), 25 (on soil, in stony meadows).

112. *T. squamosum (J.F. Gmel. : Pers.) Pers. 21 (on soil, in meadow), 26 (on soil, in meadow), 29 (on meadow above wild vines).

113. *Vascellum pratense (Pers. : Pers.) Kreisel - 14 (on sandy soil, in stony meadow), 25 (in stony meadow), 26 (on soil, in stony meadow), 29 (on soil, in pasture above wild vines), 36 (on sandy soil, roadside, near Harmanli town).

\section{General species richness}

During the present mycological study of the Mt Sakar, 113 species were collected. All registered fungal species are reported for the first time for the Mt Sakar. Of these, 88 species are reported for the first time from Toundzha Hilly Country.

The predominant part of species belongs to the class Agaricomycetes (7 orders, 30 families, 57 genera, and 110 species), other part belongs to the Pezizomycetes ( 1 orders, 1 families, 3 genera, and 3 species).

The orders Agaricales, Polyporales, and Cantharellales dominated by the number of species, namely Agaricales (74), Russulales (11), Polyporales (9), and Phallales (8). Most species were from the families: Agaricaceae (25 each), Russulaceae (11 each), Tricholomataceae (8 each), and Geastraceae (6 each), followed by Amanitaceae, Boletaceae, Entholomataceae, Hygrophoraceae, Inocybaceae, Polyporaceae, Psathyrellaceae, and Strophariaceae - with 4 
each. The greatest number of larger fungi were identified from the genera Agaricus (6), Geastrum (6), Russula (6), Hygrocybe (5), followed by Boletus, Lepista, Lycoperdon, and Tulostoma - with 4 each.

Thus thefungal diversityof Mt Sakar appears tobe diverse and with an interesting compositionof species with Mediterranean and sub-Mediterranean affinities (e.g. Agaricus bernardii, Chlorophyllum agaricoides, Entoloma incanum, Geastrum corollinum, G. minimum, $G$. pectinatum, G. striatum, Geopora arenicola, Hygrocybe virginea, $H$. persistens, Lepiota alba, Leucopaxillus lepistoides, as well as gasteroid fungi from genera Bovista, Calvatia, Tulostoma etc.).

The species composition of the larger fungi in the mountain comprises of species included in the Mediterranean area and xerothermic grasslands of some European countries: Italy (33), Greece (34), Poland (35-37), Russia and Ukraine (38-40), etc.

\section{Conservation importance}

Nine species found during this study are included in the Red List of fungi in Bulgaria (32), and Red Data Book of the Republic of Bulgaria (41) on the territory of Mt Sakar, namely Agaricus macrocarpus (EN), Amanita caesarea (VU), A. vittadinii (VU), Bovista graveolens (EN), Clathrusruber (NT), Chlorophyllum agaricoides (EN), Geastrum triplex (VU), Phallus hadriani (NT), Tulostoma fimbriatum (NT). One species rare and threatened in Bulgaria and Europe - Phallus hadriani (42).

Other interesting species found during this study

Geastrum corollinum - this is the third locality of this species in Bulgaria, so far known from the Black Sea coast (43) and Mt Strandzha (44).

G. fornicatum - this is the third locality of this species in Bulgaria, so far known from the Black Sea coast (43) and Mt Strandzha (44).

G. pectinatum - this is the third locality of this species in Bulgaria, so far known from the Black Sea coast (43) and Pirin Mts (45).

G. striatum - this species is perhaps more widespread, but so far it has been known only from three localities at the Black Sea coast (43), Znepole region (46), and Vitosha region (47).

$G$. triplex - this species has been reportedin Bulgaria from the Black Sea coast (43), Vitosha region (48), and Central Rhodopi Mts (49).
Geopora arenicola - this species has been reportedin Bulgaria from the Northern Black Seacoast (50) and Thracian Plain - Besaparski Ridove (51).

\section{CONCLUSION}

It should be underlined in conclusion that, besides being extremely important for the plant and animal conservation, Mt Sakar is equally important for the conservation of fungal diversity. The author hopes that this study will enrich information about fungal diversity of the Mt Sakar as well as for the fungal diversity to Mediterranean and sub-Mediterranean plant communities in Bulgaria, as a rule.

\section{REFERENCES}

1. Bondev, I., Geobotanical regioning. In: Geography of Bulgaria. Physical geography. Socio-economic geography. ForCom Publ. House, pp.345-349, 2002 (Bg).

2. Velev, S. Climatic regionalization. In: Geography of Bulgaria. Physical geography. Socio-economic geography. For Com Publ. House, pp. 155-157, 2002.

3. Georgiev, M., Physical Geography of Bulgaria. Science and Art Publishing House, Sofia, p. 406, 1985 (Bg).

4. Yordanova, M., Velev, S., Drenovski, I., Characteristic features of the physical geographical regions.In: Geography of Bulgaria. Physical geography. Socioeconomic geography., For Com Publ. House, pp. 409-411, 2002.

5. Ninov, N., Soil-geographic Regions. In: Geography of Bulgaria. I. Sofia, 397-405, $1982(\mathrm{Bg})$.

6. Bondev, I., Vegetation in Bulgaria-map 1:600000 with explanatory text, University Press "St. Kliment Ohridski", Sofia, 1991 (Bg).

7. Droumeva-Dimcheva, M., GyoshevaBogoeva, M., Macromycetes in Bulgaria, p. 34, 1993 (Bg).

8. Denchev, C.M., Bakalova, G.G., Centenary review of the fungal diversity investigations in Bulgaria. - Bulgarian-Swiss Biodiversity Conservation Programme, Sofia, 2002 (Bg).

9. Denchev, C.M., Gyosheva, M.M., Rossnev, B., Fungal diversity in Bulgaria - current state of investigation, conservation, and rational utilization. - In: A. Petrova [ed.]. Current state of Bulgarian biodiversity problems and perspectives. Institute of Botany, Bulgarian Academy of Sciences, Sofia, pp. 35-65, 2005 (Bg). 
10. Gjoševa, M., Macromycetes in Mediterranean and submediterranean plant communities of Bulgaria: a check list. Bocconea 5: 873-876, 1997.

11. Gyosheva, M. and Dimcheva, M., New and rare for Bulgaria macromycetes. Fitologiya, 41: 66-69, 1991 (Bg).

12. Arnolds, E., Ecology and coenology of macrofungi in grasslands and moist heathlands in Drenthe, the Netherlands, 1. J. Cramer, 1981.

13. Cappelli, A., Fungi Europaei, AgaricusL. : Fr. (PsalliotaFr.). Saronno, 1984.

14. Clémençon, H., Kompendium der Blätterpilze VI. Laccaria. Zeitschrift für Mykologie, 50: 3-12, 1984.

15. Courtecuisse, R., Duhem, B., Collins Field Guide. Mushrooms and toadstools of Britain and Europe. Harper Collins Publishers, London, 1995.

16. Contu, M., Il genere Laccaria (Basidiomycotina, Agaricales) in Italia, con note sulle rimanenti specie in Europa. Bollettino del Gruppo Mycologico $G$. Bressadola - NuovaSerie, 46(1): 5-58, 2003.

17. Dennis, R.W.G., British Ascomycetes. 2nd ed. J. Cramer, Vaduz, 1978.

18. Dissing, H., Geopora Harkness. In: Hansen,L. \& Knudsen, H. (eds). Nordic Macromycetes. Vol. 1. Ascomycetes. Nordsvamp, Kopenhagen, pp. 97-98. 2000.

19. Moser, M., Die Rohrlinge and Blatterpilze. Vol. 2b/2. Basidiomyceten. Teil (Agaricales). Stuttgart. New York, Veb. G. Fischer Verlag, p. 443, 1967.

20. Moser, M., Röhrlinge und Blätterpilze. 4 thed. Kleine Kryptogamenflora Mitteleuropas. Vol. 2b/2. G. Fischer Verlag, Stuttgart, 1978.

21. Moser, M., Key Agarics and Boleti (Polyporales, Boletales, Agaricales, Russulales), 1983.

22. Phillips, R. 1981. Mushrooms and Other Fungi of Great Britain and Europe. Pan Books Ltd. p. 287, 1981.

23. Hinkova, Ts., Stoichev, G. Leucopaxillus lepistoides (Maire) Sing. in Bulgaria. In: V. Velchev [ed.]. Third National Conference of Botany, Sofia, 26-30.X.1981, pp.39-41. Bulgarian Academy of Sciences Publishing House, Sofia, 1983b (Bg).

24. Hansen, L., Knudsen, H. Nordic Macromycetes. Vol. 2. Polyporales, Boletales, Agaricales, Russulales. Helsinki University Printing House, Helsinki, 1992.
25. Galli, R., Le Russule. Atlante praticomonografico per la determinazione delle russule. Edinatura, p. 480, 1996.

26. Neville, P., Poumarat, S., Amaniteae. In: Fungi Europaei. Vol. 9. Edizioni Candusso, Alassio, pp. 1-1120, 2004.

27. Sunhede, S., Geastraceae (Basidiomycotina). Morphology, ecology, and systematics with special emphasis on the North Europaean species. Synopsis Fungorum 1. Fungiflora - Oslo - Norway, p. 534, 1989.

28. Wasser, S. Biodiversity of Cyanoprocaryotes, Algae and Fungi of Israel. Family Agaricaceae (Fr.) Cohn. (Basidiomycetes) of Israel Mycobiota. I. Tribe Agariceae Pat. Ruggell, 2002.

29. Watling, R. Identification of the Larger Fungi. Amersham: Walton. 281 p., 1973.

30. Kirk, P.M., Cannon, P.F., David, J.C., Stalpers, J.A. Dictionary ofthe Fungi. 10 thed. CAB International, Oxon, 2008.

31. Kirk, P.M \& Ansell, A.E. Authors of Fungal Names. Electronic version. CABInternational, Wallingfort (www.indexfungorum.org/Names), 2004.

32. Gyosheva, M.M., Denchev, C.M, Dimitrova, E.G., Assyov, B., Petrova, R.D. and Stoichev, G.T., Red List of Fungi in Bulgaria. Mycologia Balcanica, 3(1): 81-87, 2006.

33. Laganá, A., Salerni, E., Barluzzi, C., Dominicis, V. and Perini, C., Fungi (Macromycetes) in various types of Mediterranean forest ecosystems (Tuscany, Italy). Polish Botanical Journal, 47(2): 143-165, 2002.

34. Zervakis, G., Dimou, D.M. and Polemis, E., Fungal diversity and conservation in the Mediterranean area:Recent advances in the inventory of Greek macromycetes. Mycologia Balcanica, 1: 31-34, 2004.

35. Łuszczyński, J., Leucopaxillus lepistoides a new steppe fungus in Poland. Acta Mycologica, 41(2): 279-284, 2006.

36. Stasińska, M., The state of knowledge of Macromycetesin xerothermic grasslands in Poland.Ann. UMCS, Biologia, 63(1): 71-78, 2008.

37. Jaworska, J., Łuszczyński, J., Łuszczyńska, B. and Tomaszewska, A., Macromycetes indicator species for xerothermic grasslands of the Chęciny district. Acta Agrobotanica, 65 (1): 63-70, 2012.

38. Vasilkov, B.P., About steppe mushrooms Agaricus bernardii (Quél.) Sacc. Botanical materials spore plants, 9: 154-157, 1953. 
39. Vassileva, L.N., Mushrooms Agaricales of Primorsky Krai. Science, Leningrad, p. 331, 1973.

40. Wasser, S.P., Soldatova, I.M., Higher Basidiomycetes steppe zone of Ukraine. Naukova Dumka, Kiev, p. 319, 1977.

41. Gyosheva, M.M., Denchev, C.M, Dimitrova, E.G., Assyov, B., Petrova, R.D. and Stoichev, G.T., Red List of Fungi inBulgaria. Mycologia Balcanica,3 (1):8187, 2006.

42. Dahlberg, A., Croneborg, H. (eds)., 33 threatened fungi in Europe. Complementary and revised information on candidates for listing in Appendix I of the Bern Convention. T-PVS document (2001) 34 rev. 2. Council of Europe, Strasbourg, 2003.

43. Kuthan, J., Kotlaba, F. Macromyzetendes National parkes, Ropotamo in Bulgarien. Sborn. Nar. Mus. v Praze Răda B, Přir. Vedy, 37(2): 77-136+ Tabs I/1-VIII, 1981.

44. Kuthan, J. \& Kotlaba, F., Makromyzeten derbulgarischen Schwarzmeerküste und einiger Orte im landesinnern Bulgariens. Sborník Národního Muzea v Praze, Řada B (Přrirodovédecká), 44(3-4)[1988]:137-243 +Photos 1-2 \& Tabs I/1-XVI/2, 1989.

45. Denchev, C.M., Fakirova, V.I., Gyosheva, M.M. and Petrova, R.D. Macromycetes in the Pirin Mts (SW Bulgaria). Acta Mycologica, 42 (1): 21-34, 2007.
46. Burzakov, B., Two truffles and some fungal species new for Bulgaria. Bulletin de la Societe Botanique de Bulgarie, 5: 84-86, $1932(\mathrm{Bg})$.

47. Hinkova, Ts., Contribution to the fungal flora of Mt Vitosha. Izvestiya na Botanicheskiya Institut (Sofia), 4: 323-351, $1955(\mathrm{Bg})$.

48. Hinkova, Ts., Contribution to the fungal flora of Bulgaria. Izvestiya $n a$ Botanicheskiya Institut (Sofia), 58(2) [1963/1964]: 95-105, 1965 (Bg).

49. Denchev, C.M., Gyosheva, M., Bakalova, G., Fakirova, V., Petrova, R., Dimitrova, E., Sameva, E., Stoykov, D., Assyov, B. and Nikolova, S., Fungal diversity of the Rhodopes (Bulgaria). - In: P. Beron [ed.]. Biodiversity of Bulgaria. Vol. 3. Biodiversity of Western Rhodopes (Bulgaria and Greece). I. Pensoft \& Natl. Mus. Natur. Hist., Sofia, pp. 81-131, 2006.

50. Hinkova,Ts., Materials on the fungal flora of Bulgaria. Izvestiya na Botanicheskiya Institut (Sofia), 8: 251-259, 1961 (Bg).

51. Assyov, B., Stoykov, D.Y., Gyosheva, M., Some rare and noteworthy larger fungi in Bulgaria. Trakia Journal of Sciences, 10(2): 1-9, 2012. 